\title{
COVID-19: AN UPDATED REVIEW
}

\author{
F.A. Isihak, M.A. Hamad, N.G. Mustafa \\ College of Veterinary Medicine, University of Mosul, Mosul, Iraq
}

\begin{abstract}
COVID-19 is a zoonotic disease that showed higher levels of transmissibility in humans. Coronavirus has the largest recognized genome $(28-33 \mathrm{~kb})$ of a positive-sense single stranded RNA. The genome composed of $5^{\prime}$-end, the translationable mRNA sequences for the key proteins; replicase, spike, envelop membrane, and nucleocapsid and $3^{\prime}$-end (polyA tail). This highly contagious virus may impair the immune system in the early phase of the disease, hence the symptoms of the disease appear very rapidly. Importantly until now, there is no efficient strategy for containing the disease. So, all the world scientists today are in a race against time to find a vaccine or treatment to COVID-19, which requires a deeper understanding.
\end{abstract}

Key words: COVID-19, SARS-CoV-2, vaccination, virus structure, epidemiology, ACE2, spikes.

\section{COVID-19: ОБНОВЛЕННЫЙ ВЗГЛЯД}

Isihak F.A., Hamad M.A., Mustafa N.G.

Колледж ветеринарной медицины, Университет Мосула, г. Мосул, Ирак

Резюме. COVID-19 является зоонозным заболеванием, для которого обнаружен более высокий уровень передачи у человека. Среди всех РНК-содержащих вирусов коронавирусы имеют наибольший размер генома (28-33 п.о.), представленный положительно-полярной нитью РНК. В частности, их геном содержит 5'-конец, транслируемые мРНК, соответствующие ключевым белкам; репликазу, белок spike (шип), белки оболочки, нуклеокапсид и 3'-конец (поли-А хвост). Этот высококонтагиозный вирус может влиять на иммунную систему на ранней стадии инфекции, из-за чего симптомы заболевания проявляются очень быстро. Важно, что до сих пор отсутствует эффективная стратегия по ограничению этого заболевания. Исходя из этого, ученые всего мира в гонке со временем заняты поиском вакцин или методов лечения COVID-19, что требует более глубокого понимания течения заболевания.

Ключевые слова: COVID-19, SARS-CoV-2, вакцинация, строение вируса, эпидемиология, ACE2, шипы.

\section{History of human coronaviruses}

Human coronaviruses originated in 1965 when it was discovered in human embryonic tracheal organ cultures attained from the respiratory tract of an adult with a common cold and the viruses named B814 [69]. These viruses were termed "OC" to describe that they were grown in organ cultures [3]. Performed electron microscopy on fluids from organ cultures infected with B814 found particles that look like the virus caused infectious bronchitis of chickens (IBV). Human coronaviruses were until 2003 recognized as a normal cause of common cold symptoms, and rarely a cause of lower respiratory tract disease, but occasionally if ever a cause of serious illness. In 2003, a novel coronavirus was established into humans from animals as the causative agent of the outbreak of severe acute respiratory syndrome (SARS). The SARS outbreak revealed that coronaviruses can be life threating human pathogens and led to the discovery of other novel human coronaviruses as well as multiple novel coronaviruses in bats, the likely reservoir for SARS coronavirus [72].

\author{
Адрес для переписки: \\ Мохаммад А. Хамад \\ Ирак, г. Мосул, ул. Аль-Маджмоа, Колледж ветеринарной \\ медицины, Университет Мосула. \\ Тел.: +9647728214770. \\ E-mail: mahmah1073@gmail.com \\ Библиографическое описание: \\ Исихак Ф.А., Хамад М.А., Мустафа Н.Г. COVID-19: обновленный взгляд // \\ Инфекция и иммунитет. 2020. Т. 10, № 2. С. 247-258. doi: 10.15789/2220- \\ 7619-CAU-1443 \\ (c) Isihak F.A., Hamad M.A., Mustafa N.G., 2020
}

\section{Contacts:}

Mohammad A. Hamad

Al Majmoaa Street, Mosul, Iraq, College of Veterinary Medicine, University of Mosul.

Phone: +964 7728214770.

E-mail: mahmah1073@gmail.com

\section{Citation:}

Isihak F.A., Hamad M.A., Mustafa N.G. COVID-19: an updated review //

Russian Journal of Infection and Immunity = Infektsiya i immunitet, 2020, vol. 10, no. 2, pp. 247-258. doi: 10.15789/2220-7619-CAU-1443

DOI: http://dx.doi.org/10.15789/2220-7619-CAU-1443 


\section{Human coronaviruses}

The four most common human coronaviruses named 229E (alpha coronavirus), NL63 (alpha coronavirus), OC43 (beta coronavirus) and HKU1 (beta coronavirus), did not jump from animals to humans but rather use humans as their biological hosts. According to the $\mathrm{CDC}$, they can cause common colds and self-limiting upper respiratory diseases in immune-competent patients. While other human coronaviruses are MERS- CoV (the beta coronavirus that causes Middle East Respiratory Syndrome, or MERS), SARS-CoV (the beta coronavirus that causes a severe acute respiratory syndrome, or SARS) and lastly SARS-CoV-2 (the novel coronavirus that causes coronavirus disease 2019, or COVID-19) (fig. 1). Sometimes coronaviruses that infect animals can evolve and make humans ill and turn out to be a new human coronavirus. Three recent examples of this are SARS-CoV-2 (COVID-19), SARS-CoV-1 and MERS-CoV [35].

\section{Shape of coronaviruses}

The virus particles were medium sized (80$150 \mathrm{~nm}$ in diameter), pleomorphic, membrane-coated (enveloped), and covered with widely spaced clubshaped surface projections (spikes) (fig. 2, color plate, p. I). Coronaviruses are a large family of zoonotic viruses that possesses the largest RNA viral genomes cause illness varying from the common cold to acute respiratory diseases [33].

\section{Epidemiology}

During 2002-2003 outbreaks, SARS infection was recorded in 29 countries in Europe, Asia, North America, and South America. Overall 8098 infected individuals were detected with 774 SARS-related deaths [13]. It is still unclear how the virus entered the human population and whether the Himalayan palm civets were the natural reservoir for the virus? The SARS epidemic gave the world of coronaviruses a huge infusion of energy and activity that contributed to the large amount already known about the virology and pathogenesis of coronavirus infections from the growing area of veterinary virology [34].

In 2012 another coronavirus capable of producing a severe acute respiratory illness later known as Middle East respiratory syndrome (MERS) was discovered in humans. The former case was found in Saudi Arabia, and others were reported within the subsequent year in France, Qatar, Jordan, Tunisia, the United Arab Emirates, Germany and the United Kingdom. All proved cases were directly or indirectly linked to the Middle East [54].

A novel coronavirus outbreak was first recognized in Wuhan, Hubei Province, China in December 2019. It has now been confirmed on six continents and in more than 150 countries. There are many coronaviruses known to be circulating in different animal populations that have not yet infected humans. On December 31 2019, Chinese authorities alerted the World Health Organization of an outbreak of a novel strain of coronavirus causing severe illness, which was subsequently named SARS-CoV-2. COVID-19 is the most current to make the jump to human infection. This new virus seems to be very communicable and has quickly spread worldwide. The dynamics of SARS-CoV-2 are currently unknown, but there is an assumption that it also has an animal origin [14]. This virus has round or elliptic and often pleomorphic shape and a diameter of approximately $60-140 \mathrm{~nm}$. Like other CoVs, it is sensitive to ultraviolet waves and heat. The whole genome of SARS-CoV-2 has an $86 \%$ resembly with SARSCoV-1 [68].

\section{Pathogenesis}

The virulence mechanisms of SARS-CoV-2 have an affinity to the function of the nonstructural proteins (Nsps) and structural proteins. For instance, research underlined that (Nsps) is able to impair the host innate immune response [65]. The envelop of the virus has an essential role in pathogenicity



Figure 1. Current international classification of coronavirus diseases in relation to virus taxonomy ICD-11 [76] 
as it supports viral assembly and release. The angiotensin-converting enzyme 2 (ACE2) that found on the cells of the lower respiratory tract of human, has been linked as the receptor used for cell endocytosis for both SARS-CoV-1 and SARS-CoV-2 (COVID-19) [85].

Among the structural component of CoVs, the spike glycoproteins consist of two subunits (S1 and S2, see below). Homotrimers of S proteins compose the spikes on the viral surface (envelop) leading the link to susceptible host receptors. In SARSCoV-2, the S2 subunit, having a fusion peptide, a transmembrane domain and cytoplasmic domain, is highly conserved. Thus, it could be the target for antiviral (anti-S2) compounds. Other structural elements on which research must necessarily focus are the ORF3b that has no homology with that of SARS-CoVs and a secreted protein (encoded by ORF8), which is structurally different from those of SARS-CoV [31].

The researchers found that the receptor-binding domain (RBD) portion of the SARS-CoV-2 spike proteins had developed to efficiently target a molecular feature on the outside of human cells called ACE2 receptors, these receptors involved in controlling of blood pressure. The spike protein of SARS-CoV-2 was so effective at binding the human cells; in fact, that the scientists achieved it was the result of natural selection and not the product of genetic engineering [4].

\section{The difference between SARS-CoVs 2020 and 2003 outbreaks}

Here we mention the main deference that includes: Firstly, the Wuhan location is different, which is the epicenter of COVID-19, joins multiple aspects that make containment challenges. As the largest city (more than 11 million people) in central China, Wuhan is a major transport center, focal point for trade and business, home to the biggest train station and largest airport [75]. Secondly, the reason might be that the infectious period is uncommon. Isolation was efficient for SARS because peak viral shedding happened after patients were already quite ill with respiratory symptoms and could be easily detected [74]. Thirdly, an explanation could be that the transmissible rate might be higher for COVID-19 than for SARS. The fourth clarification is that the clinical spectrum is different. China's initial case explanation was focused on pneumonia, and initial case fatality rates (CFR) were described at about $10 \%$ on the basis of this narrow case definition [29]. Fifth the continued spread of SARS-CoV-2 is "more infectious" but less severe than the SARS-CoV-1, and everything indicates that the mortality rate of SARSCoV-2 is lower when compared to the outbreak of SARS in 2003, as well as the stock markets around the globe dropped sharply amid intensifying concern about the economic impact of the COVID-19.

\section{SARS-CoV-2 genome}

Among a variety of viral genomes, coronavirus, the most abundant virus (including SARS-CoV-2) have the largest recognized genome $(28-33 \mathrm{~kb})$ of a non-segmented positive-sense $(+)$ single stranded RNA [4]. The genome composed of $5^{\prime}$ end (cap), has UTR and leader sequences, that is critical to mRNA transcription and replication, and $3^{\prime}$ (polyA tail) end, and in between the translationable mRNA sequences for the essential key proteins; replicase, spike, envelop membrane, and nucleocapsid [21]. About two-third $(\sim 20 \mathrm{~kb})$ of the genome create nonstructural proteins (nsps), while remaining ( $\sim 10 \mathrm{~kb})$ encodes accessory and structural proteins. Also, it should be noted that each structural and accessory genes have transcription regulatory sequences (TRSs) that are critical in each gene transcription [24]. This genome undergoes the replication in two steps producing mRNA and subgenomic mRNA (fig. 3, color plate, p. I), while the translation process directly employed host cell ribosomes depending on either nested mRNA or ribosomal frameshifting [23]. Faithfully, virus to overwhelmed of their small mRNA, it is headed for translational maneuvers a) Biosynthesis of polyprotein precursor, and b) Non-translation (subgenomic mRNA, RNA splicing, and mRNA editing). Besides that, ribosomal frameshifting as a "slyness process" validated in other viruses such as HIV and Rous sarcoma virus, also in many living organisms and in human cells, in which the individual ribosome moves to another reading frame beginning the translation. This process required at least two components: a) Sequences of slippery homopolymeric ( 7 nt), b) RNA secondary structure called pseudonot $(\sim 5-8 \mathrm{nt})$, it is thought that the aim of ribosomal frameshifting is either development of more than one polypeptide from a single mRNA and/or regulation of the developed protein activities [66].

After an attack of the prefered host cell, part of the viral genome, the 5 -open reading frame (ORF) is encoded to the biosynthesis of a polyprotein which is subsequently cleaved by the viral-encoded proteases developing several Nsps, including an RdRp and an ATPase/helicase [67]. The above proteins are liable for the viral genome replication and creation of nested transcripts which are utilized in the formation of the viral other proteins [45]. As mentioned above, SARS-CoV RNA is contagious and attends as the genome and viral mRNA, thus ORF1a and ORF1b are encoded by the genomic RNA, then the translation arises through ribosomal frameshifting (fig. 3). The resulting proteins ppla and pplab are processed into the viral polymerase $(\mathrm{RdRp})$ and other non-structural proteins involved in RNA synthesis, whereas, structural proteins are expressed as subgenomic RNAs, each RNA (genomic and subgenomic) is translated to yield only the protein encoded by the $5^{\prime}$-most ORF [60]. 
However, the genome of SARS-CoV-2 was sequenced in different centers around the world, in brief, according to [45] it is composed of 29811 nt, $(32.12 \% \mathrm{~T}, 29.86 \% \mathrm{~A}, 19.63 \% \mathrm{G}$, and $18.39 \% \mathrm{C})$, whereas recently it is demonstrated that the complete genome is $29,903 \mathrm{nt}$, it is revealed that these sequence analyses are very closely related to the previously sequenced SARS-CoV [36].

\section{SARS-CoV proteins}

\section{Spike}

A glycosylated dense protein (about $150 \mathrm{kDa}$ ) contributed to the virus pass into the cell [46]. Spike is a trimeric fusion protein adapted to the continuous conformational and structural changes triggering virus membrane fusion with the host cell membrane $[39,60]$, these changes activated when S1(see below) binds to the own receptor on the host cell membrane. The binding of S1 destabilizes trimeric protein leading to loss of $\mathrm{S} 1$ consenting to $\mathrm{S} 2$ conformational changes ensuring post-fusion stability [9], besides, after binding to the receptor, S1 receptor binding domain (RBD) transiently change it is attendance. Therefore, the spike, in addition to their key role in the host immune response and reflecting of a species and tissue determinant, spike also a considerable target of the antibody-mediated neutralization. Depending upon the crystal structural and cryo-EM studies [77] spike consists of three segments (fig. 4, color plate, p. I); a large external part, anchoring transmembrane part, and a small tail inside the virus. The large part has two subunits S1 and S1, usually, but not always, $\mathrm{S}$ protein is cleaved through a furinlike protease of the host cell into two polypeptides (S1 and S2) [21]. S1 (specified to combined to host cell membrane receptor), and S2 (act as fusion subunit with host cell membrane) (fig. 5, color plate, p. I). Furthermore, S1 consists of two parts; S1-Nterminal domain (S1-NTD) contributed to the binding to the sugar $[44,71]$, and S1-C-terminal domain
(S1-CTD) denoted to recognizing of protein domain of ACE2, APN, DPP4 receptors [18, 56], for more information about SARS-CoV receptors see table 1.

On the other hand, it is confirmed that coronavirus has two target hot spots in the human ACE2 receptor; Lys31 and Lys353, these hot spots have salt bridge inside a hydrophobic domain, it is believed that these spots play a key role in virus-receptor recognition and interaction [18]. During the SARS epidemic in 2003, interestingly, there was a high homogeneity between human and palm civet isolates of the SARS-CoV, with remarkable S1-CTDs that differ only in two residues at RBM; human SARS-CoV Asn479 and Thr487 compared to civet SARS-CoV Lys479 and Ser487, respectively [41, 60].

These residues (479 and 487) on the S1-CTD of SARS-CoV collaborate with the above mentioned hot spots, and continually vulnerable to mutations of selection, for example the two common selective mutations of SARS-CoV are K479N and S487T, endorse the hot spots activity and enhance the affinity of S1-CTD to human ACE2 [44, 49, 55]. It is generally assumed that the above two mutations play a critical role in SARS-CoV transmission from civet to man, and among humans during SARS-CoV epidemic [39, 43], another support to the key role of hot spots found in the ACE2 of rats that lack the same previously mentioned hot spots, consequently, SARS-CoV cannot interact with rat $\mathrm{ACE} 2$ receptor, and rats resist the infection [27].

\section{Papain-like protease}

Coronavirus Gene 1 encodes replicase polyproteins that are projected to be handled into 16 Nsps (Nsps 1 to 16) (tabl. 2) through the action of two proteases, a papain-like protease (PLP) and 3CLpro [53]. Papain-like protease (PLP) is a multifunctional protein, interferon adversary that establishes a domain of the replicase polyprotein, and at an initial phase of the viral replication round may be active to upset of IFN induction [7]. PLP catalyzes site-

Table 1. Common recognized receptors of coronaviruses*

\begin{tabular}{|l|l|}
\hline \multicolumn{1}{|c|}{ Viruses } & \multicolumn{1}{c|}{ Recognized receptors } \\
\hline Alphacoronavirus (HCoV-NL63) & Zinc peptidase angiotensinogen converting enzyme 2 (ACE2) [27, 38] \\
\hline Betacoronavirus (SARS-CoV) & Other zinc peptidase, aminopeptidase N (APN) [42, 44] \\
\hline Alphacoronavirus (TGEV, PEDV, PRCV) & APN [85] \\
\hline $\begin{array}{l}\text { Alphacoronavirus (TGEV, PEDV) and } \\
\text { gammacoronavirus (IBV) }\end{array}$ & Serine peptidase, Dipeptidyl peptidase 4 (DPP4) also known as CD26 [57, 79] \\
\hline MERS-CoV & Cell adhesion molecule, CEACAM1 [37] \\
\hline HKU4 & N-acetyl-9-O-acetylneuraminic acid [42] \\
\hline MHV & BCoV
\end{tabular}

*Here it must be noted that one of the unique characteristics of coronavirus their wide range of receptors. Besides, ambiguously various coronaviruses could recognize the same receptor, in contrast, the individual virus can target various receptors. Therefore, it could be suggested that the novel coronavirus currently may direct to changes their prefer receptor. 
Table 2. Size and functions of non-structural protein (Nsps) [64]

\begin{tabular}{|c|c|c|}
\hline Nsps & Size & Function \\
\hline Nsp1 & 110 a.a, $20 \mathrm{kDa}$ & $\begin{array}{l}\text { Act as a potential virulence factor, collaborated to cleave mRNA, } \\
\text { it is a target for } 40 \text { S ribosomal subunit }\end{array}$ \\
\hline Nsp2 & $70 \mathrm{kDa}$ & Disrupt intracellular signaling of the host \\
\hline Nsp3 & $214 \mathrm{kDa}$ & Replication and transcription \\
\hline Nsp4 & $56 \mathrm{kDa}$ & Transmembrane domain \\
\hline Nsp5 & $34 \mathrm{kDa}$ & Highly conserved \\
\hline Nsp6 & $33 \mathrm{kDa}$ & Transmembrane domain \\
\hline Nsp7 (nsp interactome) & 83 a.a, $10 \mathrm{kDa}$ & Cap modification, mRNA capping, and fidelity of RNA synthesis \\
\hline Nsp8 (nsp interactome) & 200 a.a, 22 kDa & Key role in RNA synthesis, primase \\
\hline Nsp9 (nsp interactome) & 110 a.a, $13 \mathrm{kDa}$ & Cap modification, mRNA capping, and fidelity of RNA synthesis \\
\hline Nsp10 (nsp interactome) & 139 a.a, $18 \mathrm{kDa}$ & $\begin{array}{l}\text { Replication cofactor, contributed to the formation of capping } \\
\text { machinery, most conserved protein }\end{array}$ \\
\hline \multicolumn{3}{|l|}{ Nsp11 } \\
\hline $\begin{array}{l}\text { Nsp12 (RNA-dependent RNA } \\
\text { polymerase, RdRp) }\end{array}$ & $102 \mathrm{kDa}$ & $\operatorname{RdRp}$ \\
\hline Nsp13 (Helicase) & 600 a.a, $66.5 \mathrm{kDa}$ & $\begin{array}{l}\text { Multifunction and highly conserved, contributed to the formation } \\
\text { of capping machinery, RNA 5' triphosphatase, site for zinc } \\
\text { binding }\end{array}$ \\
\hline Nsp14 (Exoribonuclease) & $58 \mathrm{kDa}$ & $\begin{array}{l}\text { Contributed to the formation of capping machinery, N7-Methyl } \\
\text { transferase, mismatch repair }\end{array}$ \\
\hline Nsp15 (Endoribonuclease) & $38.4 \mathrm{kDa}$ & Most conserved protein among coronaviruses proteins \\
\hline $\begin{array}{l}\text { Nsp16 (ribose 2'-O-methyl transferase, } \\
\text { 2'-O-MTase) }\end{array}$ & $33 \mathrm{kDa}$ & $\begin{array}{l}\text { Contributed to the formation of capping machinery, 2'-O-methyl } \\
\text { transferase }\end{array}$ \\
\hline
\end{tabular}

specific protein cleavage of the viral polyprotein. Also, contrasting to the accessory proteins, that can differ significantly among $\mathrm{CoV}$ species, conservation of PLP activity is key to viral duplication and is thus maintained among coronaviruses [21]. PLP catalyzes the handling of the replicase polyprotein at cleavage locations nsp1/nsp2, nsp2/nsp3, and nsp3/nsp4. PLP deubiquitinating action has been confirmed in several signaling, therefore, PLP considers a target to the development of coronavirus inhibitors [39, 82].

\section{C like main protease}

3C like main protease (3CLpro) that is Nsp5, the first enzyme that auto-cleaved from polyprotein to form mature enzymes. 3CLpro contributed to the development of other Nsps which play a critical role during the viral replication cycle. However 3CLpro consists of three parts; domain I (8-101 residues), domain II (102-184 residues), and domain III (201-303 residues), in addition to long loop (185-200 residues) connect domains I and II, forming a cavity-like structure that demonstrated as an active site of 3CLpro [51, 70].

\section{RNA dependent RNA polymerase}

RNA dependent RNA polymerase ( $R d R p)$ or Nsp12 composed of 221 residues $(25 \mathrm{kDa})$ it is one of the conservative proteins of coronavirus, it has a central role in replication/transcription complex. $\mathrm{RdRp}$ is a vital protease that catalyzes the transcription of RNA from template RNA, thus it is a target of therapeutic agents. RdRp occurs toward C terminal and three of residues (Ser, Asp, Asp) considered highly conserved [78]. Also, it is demonstrated that RdRp utilizes Nsp6 (made by Nsp8) as a primer for RNA biosynthesis, RdRp has an active site as an enormous and profound furrow for the RNA biosynthesis [60].

\section{Immunity, Vaccination and Treatment Immunity influences}

The immune cells that play a major role in the controlling of viral infection include natural killer (NK) and cytotoxic lymphocytes like cytotoxic T lymphocytes (CTLs) [38, 83]. In the sickens with COVID-19 contagion there was a markedly reduced in the overall issue of $\mathrm{NK}$ and $\mathrm{CD}^{+} \mathrm{T}$ cells [84]. According to the observations, the increased expression of $\mathrm{NKG} 2 \mathrm{~A}$ in COVID-19 sickens led to a haggard in the function of $\mathrm{NK}$ and $\mathrm{CD}^{+} \mathrm{T}$ cells. While the sickens that convalesced after therapy, showed the restored normal numbers of $\mathrm{NK}$ and $\mathrm{CD} 8^{+} \mathrm{T}$ cells with a reduction in expression of NKG2A [83, 84]. This group evidence proposes that the functional exhaustion of cytotoxic lymphocytes is correlated with SARS-CoV-2 
contagion. So, COVID-19 may destroy antiviral immunity in early-stage [84]. Also, the COVID-19 infection diminished the levels of CD107a, interferon (IFN)- $\gamma$, interleukin (IL)-2, granzyme B, and tumor necrosis factor (TNF) $\alpha[63,84]$.

According to the obtained data from comparing among three groups of people; healthy group (HG), mild cases (MC) and severe cases (SC), the effects of SARS-CoV-2 were proved clearly on NK, T cell and $\mathrm{CD}^{+} \mathrm{T}$ cell counts. Where $\mathrm{T}$ cell and $\mathrm{CD} 8^{+}$ $\mathrm{T}$ cell numbers were lessened markedly in MC and SC sickens in comparison with those in HG. Whereas, The count of $\mathrm{T}$ cells and $\mathrm{CD} 8^{+} \mathrm{T}$ cells were mainly lower in SC sickens than that in MC cases. The numbers of NK cells were minimized significantly in SC sickens in comparison with those in MC cases and HG. Of course depending on the results of treatment the diseased cases ( $\mathrm{MC}, \mathrm{SC}$ ) randomly with one of the following medication (Kaletra ${ }^{\circledR}$, Chloroquine phosphate, Interferon) plus antibiotics; these medications contributed in the restored the normal numbers of $\mathrm{NK}, \mathrm{T}$ cell and $\mathrm{CD}^{+} \mathrm{T}$ cell in the convalescent people and reduced the ratio of $\mathrm{NKG}_{2} \mathrm{~A}^{+} \mathrm{NK}$ cells [84].

The main immune influence manifestation in COVID-19 is the leukopenia with WBC numbers of $2.91 \times 10^{9}$ cells/L and $70 \%$ of them were the neutrophils. Also, markedly raise blood levels of cytokines and chemokines were recorded in sickens with COVID-19 contagion that included MIP1 $\alpha$, MIP1 $\beta$, PDGFB, TNF $\alpha$, IL-1- $\beta$, IL-1RA, IL-7, IL-8, IL-9, IL-10, basic FGF2, G-CSF, GM-CSF, IFN $\gamma$, IP-10, MCP-1, and VEGF-A. In several acute-phase patients that were turned to the intensive nursing, unit manifested rise levels of pro-inflammatory cytokines inclusive IL-2, IL-7, IL-10, G-CSF, IP-10, MCP-1, MIP- $1 \alpha$, and TNF $\alpha$ that are explain to promote illness severity [5, 29].

The suppression of innate immune responses is one of the main keys in most of the viral infections and respiratory viruses from them, so they have the chance for their adequate replication and causing the disease. The outcomes for the host's immune response are that it is predominating imperfect, belated or lessened, or exhibit too strong inducement (after the lateness) that may result in tissue damage. The influenced innate immune response also affects following adaptive responses, and thus viral innate immune escape oftentimes subverts entirely protective immunity [32].

\section{Vaccination and treatment strategies}

COVID-19 is the third extremely pathogenic coronavirus infecting human beings in the $21^{\text {st }}$ century after the MERS-CoV and SARS-CoV. Paradoxically, even after many years of research on coronavirus, as yet there are no authorized vaccines or curative agents to cure coronavirus contagion that point an imperative necessity to evolve efficacious vaccines or post-exposure prophylaxis to prevent upcoming epidemics [12, 13, 20, 62].

Notable exertions have been made to evolve therapeutic interference versus coronavirus infection. Principal explorer concentrated on recognize antiviral molecules that can be attacking the spike protein as it intermediate viral entrance, and their prospects in stimulate host immune responses and triggering preventive antibody responses in infected persons $[46,62]$.

As is known, until the present time there are no efficient vaccines or anti-viral therapeutic agents were confirmed to cure COVID-19 or any other human CoV hitting. The existing path to coronavirus disease management focuses on supportive care. Quick generic health interferences with antibodies, anti-virals or novel vaccine strategies are quite fundamental to stem the virus and illness transition. Nevertheless, there is an imperative requirement to behold new remedies for curing clinically advanced cases to minify deaths, virus propagation and to relieve the possible future outbreaks [59].

In general, there are many strategies to defense or contain the COVID-19.

1) Passive antibody cure: can be deemed as a route to boundary COVID-19 epidemics. Passive fortification of antibodies that will recognize the epitopic zone in the strange virus particle can minify the virus proliferation and disease intensity. Antibodies for passive immunotherapy could be secluded from the blood of the ills or it could be produced in the laboratories. Immuno-cure by relocating the convalescence sera to the sickens may be efficient in humans through neutralizing the virus and prohibit more infection. Depending on the existent proves and former expertise in the therapy of other viral contagions like Ebola, SARS, MERS, and influenza, the soon donation of convalescence sera or hyper-immune immunoglobulin from sickens that having highly antibody titers can probably decrease the viral load and the deaths $[6,15,47,48,50,80]$. The simple below figure 6 (see color plate, p. II), summarizes the main purpose of using passive immunity.

Obstacles for this way: Availability of adequate donors, severity or clarity of clinical condition, the viral kinetics, and host interactions of COVID-19 required to be clarified before recommending convalescent plasma as a preference treatment [26, 62]. Tiziana Life Sciences produced a monoclonal antibody known as TZLS-501, which can be used for the therapy of COVID-19. It's a human anti-interleukin-6 receptor (IL-6R), which helps in preventing lung injury.

2) Vaccines: COVID-19 challenge the world and the biggest vaccine producing companies.

This paragraph summarizes the main problem that facing the world because the principles rules of universal vaccines producing companies are the economic benefits and the funding, so the main problem is the worry of these companies about the passing and 
end of this pandemic before their vaccines are ready for marketing. Where, vaccine production has many principles steps that spending long periods, and may require several months or up to a year. For these obstacles, we wrote the above paragraph "COVID-19 challenge the world and the biggest vaccine producing companies". Therefore, the task should not be the responsibility of vaccine manufacturing companies alone, but rather there must be global cooperation and support for these companies to intensify efforts and try to produce an effective vaccine in abundant numbers at low cost to be available to all, and this requires as we mentioned cooperation at the global level as well Relevant organizations such as the WHO, FDA, and others. The steps of vaccine production and marketing include:

a. Choice the main particle of virus for using as antigen (RNA, spikes, Viral proteins...) and the precursor of a vaccine,

b. The modification method to produce an attenuated or avirulent vaccine,

c. Evaluation of in vitro responses or reactions,

d. Evaluation of in vivo responses in laboratory animals,

e. Evaluation of the safety of the vaccine (Include the dosage, route of administration, single or multiple doses),

f. Evaluation of the results of the clinical trials on volunteers.

Depending on all the previous results, obtaining approval from the authorized official authorities such as the WHO or American Organization of FDA.

Several well-known companies have conducted experiments to produce a vaccine for this pandemic that under trial or in different partial steps of the proving and below some examples:

- Vaccine by Medicago company: Produced viruslike particles (VLP) of the coronavirus, and developed antibodies against SARS-CoV-2.

- Altimmune's intranasal coronavirus vaccine: produce of the monocular-dose inoculates has been accomplished, however, animal experiences will go after.

- INO-4800: production by Inovio Pharmaceuticals and Beijing Advaccine Biotechnology. An innovative coronavirus inoculation. The company began pre-clinical experiences for clinical product industrialization.

- mRNA-1273 vaccine: Manufactured by Moderna and Vaccine Research Center. The vaccine goals the Spike (S) protein of the coronavirus.

- Avian Coronavirus Infectious Bronchitis Virus (IBV) vaccine: Manufactured and modified in MIGAL Research Institute in Israel for therapy of COVID-19.

- TNX-1800: Manufactured by Tonix Pharmaceuticals. It's a modified horsepox virus.

- Recombinant subunit vaccine: Producing by Clover Biopharmaceuticals. The vaccine based on the trimeric S protein (S-Trimer) of the COVID-19 coronavirus, which is accountable for adhering with the host cells and occurring a viral infection.

- Vaxart's coronavirus vaccine: An oral recombinant vaccine in tablet formulation.

Interferon: The cellular tracers able to disclosed viruses and stimulate the expression of the Interferon type 1 (I IFNs) that divided to IFN $\alpha$ and IFN $\beta$. Type I IFNs link to the ubiquitously expressed IFNAR (IFN $\alpha / \beta$ receptor), stimulating the JAK/ STAT pathway [19].

The release of I IFN stimulates the expression of hundreds of interferon stimulating genes (ISGs) whose firstly serve to edge the further virus spread and contagion. Also, type I IFNs can straightly stimulate immune cells(e.g., stimulating phagocytosis, dendritic cell maturation), and indirectly starting immune responses (e.g., induce the producing of chemokines and cytokines by respiratory cells). Substantial antiviral vigor by type I IFNs implicate declining viral processes such as cell entrance, proliferation, transcription, and translation [61]. Other ISG products can degrade viral nucleic acids or proteins, and many ISGs have yet to be fully characterized. In addition to their principal antiviral reaction, type I IFNs Induce the beginning of the adaptive immune response by interceding dendritic cell (DC) activation, improving effector functions of lymphocytes and macrophages, and inducing the humoral (antibody) response for neutralizing the virus [19, 52]. For all benefits of Interferon, the researchers referred to it as a defense appliance for warfare against SARS-CoV-2.

Tiny-molecule drugs to warfare COVID-19: Several medications that are also under trial or in different partial steps of proving, were announced [16] and including:

- Chloroquine phosphate: It showed effectiveness in the therapy of symptoms of the illness, among the 30 medications that were used. Ills treated with the drug showed the best decline in fever and faster recovery time in clinical experiences that carried out in hospitals in the Guangdong governorate and $\mathrm{Hu}-$ nan governorate. Where up to date the world's attention is directed toward the results of this medicine.

- Favilavir: It revealed efficiency in therapy the disease with negligible side properties in a clinical trial encompassing 70 Sickens in China.

- AT-100 (rhSP-D): It produces by Airway Therapeutics, effective in preclinical studies and diminishes inflammation and lung infection, and also produce the immune response for various respiratory illnesses.

- OYA1: production by OyaGen. Strong antiviral effectiveness for coronavirus in a laboratory experience.

- BPI-002: by BeyondSpring company. It's a tiny molecule referred for therapy different contagions including COVID-19. It can stimulate $\mathrm{CD}^{+}$ helper $\mathrm{T}$ cells and $\mathrm{CD} 8^{+}$cytotoxic $\mathrm{T}$ cells and producing an immune response against the virus. 
Table 3. Antimicrobial peptides in the the respiratory system [81]

\begin{tabular}{|l|l|}
\hline \multicolumn{1}{|c|}{$\begin{array}{c}\text { Antimicrobial peptides } \\
\text { in the respiratory tract }\end{array}$} & \multicolumn{1}{c|}{ Produced by cell } \\
\hline Alpha-Defensins (HNP1-4) & Neutrophils \\
\hline Alpha-Defensins (HNP5) & Epithelial \\
\hline Beta-Defensins (HBD1-4) & $\begin{array}{l}\text { Epithelial, Macrophages, } \\
\text { Monocytes, Dendritic }\end{array}$ \\
\hline LL-37 & Epithelial, Neutrophils \\
\hline Lysozyme & Epithelial, Neutrophils \\
\hline Lactoferrin & Epithelial, Neutrophils \\
\hline Anionic peptides & Epithelial \\
\hline
\end{tabular}

- Ivermectin: The main using of ivermectin as antparasitic, while a very recent study approved that this drug has anti-viral efficacy in vitro and inhibit the SARS-CoV-2 [10].

- Other medications like NP-120 (Ifenprodil) by Algernon Pharma, APN01 by University of British Columbia and APEIRON Biologics.

Antimicrobial peptides (AMPs): Referred as "host defense peptides (HDPs)", a portion of the innate immune response exist in every type of lifetime. Basic differences find between prokaryotic and eukaryotic cells represented by the effects of antimicrobial peptides, which produced by the eukaryotic cells and some bacteria. These peptides are powerful, wide spectrum antimicrobial which proved potency as new curative factors. These peptides have been confirmed to destroy Gram-negative and Grampositive bacteria, viruses, fungi and even convert or cancerous cells [25, 58].

The more bountiful antimicrobial peptides in the respiratory system of mammals are lysozymes, lactoferrin, histatins, defensins, and cathelicidins [8, 25]. AMPs are found in numerous kinds of tissues inclusive skin, eyes, oral bore, ears, airway, lung, female genital system, vaginal secretion, bowels, and urinary system $[1,17]$.

The defensins and the cathelicidin LL-37 are the best AMPs were thoughtful in humans, and importantly they have the immunomodulatory effect [2, 28]. AMPs as curative stuff appear particularly promised versus to emerging contagious viruses, which none confirmed vaccines or medications are presently ready, such as dengue virus (DENV) and Zika virus (ZIKV) [81]. Table 3 summarized the antimicrobial peptides that found in the respiratory system.

3) Herd immunity: Some researchers, and scientific and media channels suggested using the herd immunity method for containing the COVID-19. Whereas, the WHO criticized it, and mentioned that far greater activity is needed. Other health pundits said this pathway is empirical at bestead, and serious at worse. Herd immunity means letting a large number of people catch a disease, and hence develop immunity to it, to stop the virus spreading [22].

The meaning of herd immunity is permitting a great count of people to get a disease, so they develop immunity to it, which helps to pause the virus pervasion. Herd immunity is explained in the figure 7 (see color plate, p. II).

Finally, inclusive approaches to minify personto-person passing of COVID-19 are wanted to control the existing pandemic. Special attentiveness and efforts to safeguard or minimize transmission must be applied in sensitive inhabitants inclusive children, health care providers, and old people. A guideline was issued for the medical staff, healthcare providers, and, public health persons and scientists who are concerned in the 2019-nCoV [30]. The early dying cases of COVID-19 contagion happened mainly in elderly persons, perhaps due to a weakened immune system that authorized quicker development of viral infection $[40,73]$.

\section{Conclusion}

1. COVID-19 is the biggest challenge to the world in the $21^{\text {st }}$ century.

2. It should be remembered that one of the unique features of COVID-19 is a high rate of mutations.

3. COVID-19 may destroy antiviral immunity in the early stage.

4. There is no efficient containing for the disease, although there are many suggested strategies.

5. Strict public health measures have a reasonable role in reducing the spread of the epidemic.

6. Certain drugs, such as (hydroxy) Chloroquine, Kaletra, and Ivermectin perhaps promising in the treatment of COVID-19.

\section{References}

1. Agier J., Efenberger M., Brzezińska-Błaszczyk E. Cathelicidin impact on inflammatory cells. Cent. Eur. J. Immunol., 2015, vol. 40, pp. 225-235.

2. Ahmed A., Siman-Tov G., Hall G., Bhalla N., Narayanan A. Human antimicrobial peptides as therapeutics for viral infections. Viruses, 2019, vol. 11: 704. doi: 10.3390/v11080704

3. Almeida J.D., Tyrrell D.A. The morphology of three previously uncharacterized human respiratory viruses that grow in organ culture. J. Gen. Virol., 1967, vol. 1, pp. 175-178.

4. Andersen K.G., Rambaut A., Lipkin W.I., Holmes E.C., Garry R.F. The proximal origin of SARS-CoV-2. Nat. Med., 2020. doi: 10.1038/s41591-020-0820-9

5. André P., Denis C., Soulas C., Bourbon-Caillet C., Lopez J., Arnoux T., Bléry M., Bonnafous C., Gauthier L., Morel A., Rossi B., Remark R., Breso V., Bonnet E., Habif G., Guia S., Lalanne A.I., Hoffmann C., Lantz O., Fayette J., Boyer-Chammard A., Zerbib R., Dodion P., Ghadially H., Jure-Kunkel M., Morel Y., Herbst R., Narni-Mancinelli E., Cohen R.B., Vivier E. Anti- 
NKG2A mAb is a checkpoint inhibitor that promotes anti-tumor immunity by unleashing both T and NK cells. Cell, 2018, vol. 7, pp. 1731-1743. doi: 10.1016/j.cell.2018.10.014

6. Arabi Y., Balkhy H., Hajeer A.H., Bouchama A., Hayden F.G., Al-Omari A., Al-Hameed F.M., Taha Y., Shindo N., Whitehead J., Merson L., AlJohani S., Al-Khairy K., Carson G., Luke T.C., Hensley L., Al-Dawood A., Al-Qahtani S., Modjarrad K., Sadat M., Rohde G., Leport C., Fowler R. Feasibility, safety, clinical, and laboratory effects of convalescent plasma therapy for patients with Middle East respiratory syndrome coronavirus infection: a study protocol. Springerplus, 2015, vol. 4, p. 709. doi: 10.1186/s40064015-1490-9

7. Báez-Santos Y.M., John S.E.S., Mesecar A.D. The SARS-coronavirus papain-like protease: structure, function and inhibition by designed antiviral compounds. Antiviral Res., 2015, vol. 115, pp. 21-38. doi: 10.1016/j.antiviral.2014.12.015

8. Beisswenger C., Bals R. Antimicrobial peptides in lung inflammation. Chem. Immunol. Allergy, 2005, vol. 86, pp. 55-71. doi: 10.1159/000086651

9. Bosch B.J., van der Zee R., de Haan C.A., Rottier P.J. The coronavirus spike protein is a class I virus fusion protein: structural and functional characterization of the fusion core complex. J. Virol., 2003, vol. 77, pp. 8801-8811. doi: 10.1128/jvi.77.16.88018811.2003

10. Caly L., Druce J.D., Catton M.G., Jans D.A., Wagstaff K.M. The FDA approved drug ivermectin inhibits the replication of SARSCoV-2 in vitro. Antiviral Res., 2020: 104787. doi: 10.1016/j.antiviral.2020.104787

11. Casadevall A., Pirofski L. The convalescent sera option for containing COVID-19. J. Clin. Invest., 2020, vol. 130, no. 4, pp. 15451548. doi: 10.1172/JCI138003

12. CDC. In the absence of SARS-CoV transmission worldwide: guidance for surveillance, clinical and laboratory evaluation, and reporting version 2. URL: https://www.cdc.gov/sars/surveillance/absence.pdf

13. CDC. Interim clinical guidance for management of patients with confirmed coronavirus disease (COVID-19). URL: https://www. cdc.gov/coronavirus/2019-ncov/hcp/clinical-guidance-management-patients.html

14. Chan J.F., Kok K.H., Zhu Z., Chu H., To K.K., Yuan S., Yuen K.Y. Genomic characterization of the 2019 novel human-pathogenic coronavirus isolated from a patient with atypical pneumonia after visiting Wuhan. Emerg. Microbes Infect., 2020, vol. 9, pp. 221-236. doi: 10.1080/22221751.2020.1719902

15. Chan K.H., Chan J.F., Tse H., Chen H., Lau C.C., Cai J.P., Tsang A.K., Xiao X., To K.K., Lau S.K., Woo P.C., Zheng B.J., Wang M., Yuen K.Y. Cross-reactive antibodies in convalescent SARS patients' sera against the emerging novel human coronavirus EMC (2012) by both immunofluorescent and neutralizing antibody tests. J. Infect., 2013, vol. 67, pp. 130-140.

16. Chen N., Zhou M., Dong X., Qu J., Gong F., Han Y., Qiu Y., Wang J., Liu Y., Wei Y., Xia J., Yu T., Zhang X., Zhang L. Epidemiological and clinical characteristics of 99 cases of 2019 novel coronavirus pneumonia in Wuhan, China: a descriptive study. Lancet, 2020, vol. 395, pp. 507-513. doi: 10.1016/S0140-6736(20)30211-7

17. De la Fuente-Nunez C., Silva O.N., Lu T.K., Franco O.L. Antimicrobial peptides: role in human disease and potential as immunotherapies. Pharmacol. Ther., 2017, vol. 178, pp. 132-140.

18. Du L., Zhao G., Kou Z., Ma C., Sun S., Poon V.K., Lu L., Wang L., Debnath A.K., Zheng B.J., Zhou Y., Jiang S. Identification of a receptor-binding domain in the $\mathrm{S}$ protein of the novel human coronavirus Middle East respiratory syndrome coronavirus as an essential target for vaccine development. J. Virol., 2013, vol. 87, pp. 9939-9942.

19. Durbin R.K., Kotenko S.V., Durbin J.E. Interferon induction and function at the mucosal surface. Immunol. Rev., 2013, vol. 255, pp. 25-39. doi: 10.1111/imr.12101

20. FDA. Coronavirus Disease 2019 (COVID-19). URL: https://www.fda.gov/emergency-preparedness-and-response/counterterrorismand-emerging-threats/coronavirus-disease-2019-covid-19

21. Fehr A.R., Perlman S. Coronaviruses: an overview of their replication and pathogenesis. Methods Mol. Biol., 2015, vol. 1282, pp. 1-23. doi: 10.1007/978-1-4939-2438-7-1

22. Fine P., Eames K., Heymann D.L. Herd Immunity: a rough guide. Clin. Infect. Dis., 2011, vol. 52, pp. 911-916. doi: 10.1093/cid/ cir007

23. Flint J., Racaniello V.R., Rall G.F., Skalka A.M. Principles of virology. $4^{\text {th }}$ ed. Washington, DC: ASAM Press, 2015.

24. Forni D., Cagliani R., Clerici M., Sironi M. Molecular evolution of Human Coronavirus genomes. Trends Microbiol., 2017, vol. 25, pp. 35-48. doi: 10.1016/j.tim.2016.09.001

25. González-García M., Ständker L., Otero-González A.J. Antimicrobial peptides in multiresistant respiratory infections. Rev. Cubana Med. Trop., 2019, vol. 71, no. 2, pp. 1-16.

26. Gralinski L.E., Menachery V.D. Return of the coronavirus: 2019-nCoV. Viruses, 2020, vol. 12, p. 2. doi: 10.3390/v12020135

27. Hofmann H, Simmons G., Rennekamp AJ, Chaipan C., Gramberg T., Heck E., Geier M., Wegele A., Marzi A., Bates P., Pöhlmann S. Highly conserved regions within the spike proteins of human coronaviruses 229E and NL63 determine recognition of their respective cellular receptors. J. Virol., 2006, vol. 80, pp. 8639-8652.

28. Hsieh N., Hartshorn K.L. The role of antimicrobial peptides in influenza virus infection and their potential as antiviral and immunomodulatory therapy. Pharmaceuticals (Basel), 2016, vol. 9, pp. 3. doi: 10.3390/ph9030053

29. Huang C., Wang Y., Li X., Ren L., Zhao J., Hu Y., Zhang L., Fan G., Xu J., Gu X., Cheng Z., Yu T., Xia J., Wei Y., Wu W., Xie X., Yin W., Li H., Liu M., Xiao Y., Gao H., Guo L., Xie J., Wang G., Jiang R., Gao Z., Jin Q., Wang J., Cao B. Clinical features of patients infected with 2019 novel coronavirus in Wuhan, China. Lancet, 2020, vol. 395, pp. 497-506. doi: 10.1016/S0140 6736(20)30183-5

30. Jin Y.H., Cai L., Cheng Z.S., Cheng H., Deng T., Fan Y.P., Fang C., Huang D., Huang L.Q., Huang Q., Han Y., Hu B., Hu F., Li B.H., Li Y.R., Liang K., Lin L.K., Luo L.S., Ma J., Ma L.L., Peng Z.Y., Pan Y.B., Pan Z.Y., Ren X.Q., Sun H.M., Wang Y., Wang Y.Y., Weng H., Wei C.J., Wu D.F., Xia J., Xiong Y., Xu H.B., Yao X.M., Yuan Y.F., Ye T.S., Zhang X.C., Zhang Y.W., Zhang Y.G., Zhang H.M., Zhao Y., Zhao M.J., Zi H., Zeng X.T., Wang Y.Y., Wang X.H.; for the Zhongnan Hospital of Wuhan University Novel Coronavirus Management and Research Team, Evidence-Based Medicine Chapter of China International Exchange and Promotive Association for Medical and Health Care (CPAM). A rapid advice guideline for the diagnosis and 
treatment of 2019 novel coronavirus (2019-nCoV) infected pneumonia (standard version). Mil. Med. Res., 2020, vol. 7, no. 4. doi: 10.1186/s40779-020-0233-6

31. Kahn J., McIntosh K. History and recent advances in coronavirus discovery. Pediatr. Infect. Dis. J., 2005, vol. 24, iss. 11, pp. S223-S227. doi: 10.1097/01.inf.0000188166.17324.60

32. Kikkert M. Innate immune evasion by human respiratory RNA viruses. J. Innate Immun., 2020, vol. 12, pp. 4-20. doi: $10.1159 / 000503030$

33. Lai M.M., Holmes K.V. Coronaviridae: the viruses and their replication. In: Fields Virology. Eds. Knipe D.M., Howley P.M. Philadelphia, PA: Lippincott-Raven, 2001.

34. Lai M.M., Holmes K.V. Coronaviruses. In: Fields Virology. Eds.: Knipe D.M., Howley P.M., Griffin D.E., Lamb R.A., Martin M.A., Roizman B., Straus S.E. Philadelphia, PA: Lippincott Williams \& Wilkins, 2001, pp. 1163-1185.

35. Lei J., Kusov Y, Hilgenfeld R. Nsp3 of coronaviruses: Structures and functions of a large multi-domain protein. Antiviral Res., 2018, vol. 149, pp. 58-74.

36. Letko M., Marzi A., Munster V. Functional assessment of cell entry and receptor usage for SARS-CoV-2 and other lineage B betacoronaviruses. Nat. Microbiol., 2020, vol. 10, pp. 562-569. doi: 10.1038/s41564-020-0688-y

37. Lewicki D.N., Gallagher T.M. Quaternary structure of coronavirus spikes in complex with carcino embryonic antigen-related cell adhesion molecule cellular receptors. J. Biol. Chem., 2002, vol. 277, pp. 19727-19734. doi: 10.1074/jbc.M201837200.

38. Li F. Structural analysis of major species barriers between humans and palm civets for severe acute respiratory syndrome coronavirus infections. J. Virol., 2008, vol. 82, pp. 6984-6991.

39. Li F. Structure, function, and evolution of coronavirus spike proteins. Annu. Rev. Virol., 2016, vol. 3, pp. 237-261. doi: 10.1146/ annurev-virology-110615-042301

40. Li Q., Guan X., Wu P., Wang X., Zhou L., Tong Y., Ren R., Leung K.S.M., Lau E.H.Y., Wong J.Y., Xing X., Xiang N., Wu Y., Li C., Chen Q., Li D., Liu T., Zhao J., Liu M., Tu W., Chen C., Jin L., Yang R., Wang Q., Zhou S., Wang R., Liu H., Luo Y., Liu Y., Shao G., Li H., Tao Z., Yang Y., Deng Z., Liu B., Ma Z., Zhang Y., Shi G., Lam T.T.Y., Wu J.T., Gao G.F., Cowling B.J., Yang B., Leung G.M., Feng Z. Early transmission dynamics in Wuhan, China, of novel coronavirus-infected pneumonia. N. Engl. J. Med., 2020, vol. 382, pp. 1199-1207. doi: 10.1056/NEJMoa2001316

41. Li S.W., Wang C.Y., Jou Y.J., Huang S.H., Hsiao L.H., Wan L., Lin Y.J., Kung S.H., Lin C.W. SARS coronavirus papain-like protease inhibits the TLR7 signaling pathway through removing Lys63-linked polyubiquitination of TRAF3 and TRAF6. Int. J. Mol. Sci., 2016, vol. 17, no. 5, p. 678. doi: 10.3390/ijms17050678

42. Li W., Hulswit R.J.G., Widjaja I., Raj V.S., McBride R., Peng W., Widagdo W., Tortorici M.A., van Dieren B., Lang Y., van Lent J.W.M., Paulson J.C., de Haan C.A.M., de Groot R.J., van Kuppeveld F.J.M., Haagmans B.L., Bosch B.J. Identification of sialic acid-binding function for the Middle East respiratory syndrome coronavirus spike glycoprotein. Proc. Natl. Acad. Sci., 2017, vol. 114, pp. E8508-E8517. doi: 10.1073/pnas.1712592114

43. Lin H.X., Feng Y., Wong G., Wang L., Li B., Zhao X., Li Y., Smaill F., Zhang C. Identification of residues in the receptor-binding domain (RBD) of the spike protein of human coronavirus NL63 that are critical for the RBD-ACE2 receptor interaction. J. Gen. Virol., 2008, vol. 89, pp. 1015-1024. doi: 10.1099/vir.0.83331-0

44. Liu C., Tang J., Ma Y., Liang X., Yang Y., Peng G., Qi Q., Jiang S., Li J., Du L., Li F. Receptor usage and cell entry of porcine epidemic diarrhea coronavirus. J. Virol., 2015, vol. 89, pp. 6121-6125.

45. Lu H. Drug treatment options for the 2019-new coronavirus (2019-nCoV). Biosci. Trends., 2020, vol. 14, pp. 69-71. doi: 10.5582/ bst.2020.01020

46. Lu R., Zhao X., Li J., Niu P., Yang B., Wu H., Wang W., Song H., Huang B., Zhu N., Bi Y., Ma X., Zhan F., Wang L., Hu T., Zhou H., Hu Z., Zhou W., Zhao L., Chen J., Meng Y., Wang J., Lin Y., Yuan J., Xie Z., Ma J., Liu W.J., Wang D., Xu W., Holmes E.C., Gao G.F., Wu G., Chen W., Shi W., Tan W. Genomic characterisation and epidemiology of 2019 novel coronavirus: implications for virus origins and receptor binding. Lancet, 2020, vol. 395, no. 10224, pp. 565-574. doi: 10.1016/S01406736(20)30251-8

47. Luke T.C., Kilbane E.M., Jackson J.L., Hoffman S.L. Meta-analysis: convalescent blood products for Spanish influenza pneumonia: a future H5N1 treatment? Ann. Intern. Med., 2006, vol. 145, pp. 599-609.

48. Mair-Jenkins J., Saavedra-Campos M., Baillie J.K., Cleary P., Khaw F.M., Lim W.S., Makki S., Rooney K.D., Nguyen-VanTam J.S., Beck C.R.; Convalescent Plasma Study Group. The effectiveness of convalescent plasma and hyperimmune immunoglobulin for the treatment of severe acute respiratory infections of viral etiology: a systematic review and exploratory meta-analysis. J. Infect. Dis., 2015, vol. 211, pp. 80-90. doi: 10.1093/infdis/jiu396

49. Mou H., Raj V.S., van Kuppeveld F.J., Rottier P.J., Haagmans B.L., Bosch B.J. The receptor binding domain of the new MERS coronavirus maps to a 231-residue region in the spike protein that efficiently elicits neutralizing antibodies. J. Virol., 2013, vol. 87, pp. 9379-9383. doi: 10.1128/JVI.01277-13

50. Mupapa K., Massamba M., Kibadi K., Kuvula K., Bwaka A., Kipasa M. Treatment of Ebola hemorrhagic fever with blood transfusions from convalescent patients. International Scientific and Technical Committee. J. Infect. Dis., 1999, vol. 179, pp. 18-23.

51. Muramatsu T., Takemoto C., Kim Y.T., Wang H., Nishii W., Terada T., Shirouzu M., Yokoyama S. SARS-CoV 3CL protease cleaves its C-terminal autoprocessing site by novel subsite cooperativity. Proc. Natl. Acad. Sci. USA, 2016, vol. 113, pp. 1299713002. doi: 10.1073/pnas.1601327113

52. Newton A.H., Cardani A., Braciale T.J. The host immune response in respiratory virus infection: balancing virus clearance and immunopathology. Semin. Immunopathol., 2016, vol. 38, pp. 471-482. doi: 10.1007/s00281-016-0558-0

53. Niemeyer D., Mösbauer K., Klein E.M., Sieberg A., Mettelman R.C., Mielech A.M., Dijkman R., Baker S.C., Drosten C., Müller M.A. The papain-like protease determines a virulence trait that varies among members of the SARS-coronavirus species. PLoS Pathog., 2018, vol. 14: e1007296. doi: 10.1371/journal.ppat.1007296

54. Nour R., Houssam S. Middle East respiratory syndrome coronavirus (MERS-CoV): a review. Germs, 2019 , vol. 9, pp. 35-42. doi: 10.18683/germs.2019.1155 
55. Peng G., Xu L., Lin Y.L., Chen L., Pasquarella J.R., Holmes K.V., Li F. Crystal structure of bovine coronavirus spike protein lectin domain. J. Biol. Chem., 2012, vol. 287, pp. 41931-41938. doi: 10.1074/jbc.M112.418210

56. Promkuntod N., van Eijndhoven R.E., de Vrieze G., Gröne A., Verheije M.H. Mapping of the receptor-binding domain and amino acids critical for attachment in the spike protein of avian coronavirus infectious bronchitis virus. Virology, 2014, vol. 448, pp. 26-32.

57. Raj V.S., Mou H., Smits S.L., Dekkers D.H., Müller M.A., Dijkman R., Muth D., Demmers J.A., Zaki A., Fouchier R.A., Thiel V., Drosten C., Rottier P.J., Osterhaus A.D., Bosch B.J., Haagmans B.L. Dipeptidyl peptidase 4 is a functional receptor for the emerging human coronavirus-EMC. Nature, 2013, vol. 495, pp. 251-254. doi: 10.1038/nature12005

58. Reddy K.V., Yedery R.D., Aranha C. Antimicrobial peptides: premises and promises. Int. J. Antimicrob. Agents, 2004, vol. 24, pp. 536-547. doi: 10.1016/j.ijantimicag.2004.09.005PMID15555874

59. Rothana H.A., Byrareddy S.N. The epidemiology and pathogenesis of coronavirus disease (COVID-19) outbreak. J. Autoimmun., 2020, vol. 109: 102433. doi: 10.1016/j.jaut.2020.102433

60. Sah R., Rodriguez-Morales A.J., Jha R., Chu D.K.W, Gu H., Peiris M., Bastola A., Lal B.K., Ojha H.C., Rabaan A.A., Zambrano L.I., Costello A., Morita K., Pandey B.D., Poon L.L.M. Complete Genome Sequence of a 2019 Novel Coronavirus (SARS-CoV-2) Strain Isolated in Nepal. Microbiol. Resour. Announc., 2020, vol. 9: e00169-20. doi: 10.1128/MRA.00169-20

61. Samuel C.E . Antiviral actions of interferons. Clin. Microbiol. Rev., 2001, vol. 14, pp. 778-809. doi: 10. 1128/CMR.14.4.778-809.2001

62. Shanmugaraj B., Siriwattananon K., Wangkanont K., Phoolcharoen W. Perspectives on monoclonal antibody therapy as potential therapeutic intervention for Coronavirus disease-19 (COVID-19). Asian Pac. J. Allergy Immunol., 2020, vol. 38, pp. 10-18. doi: 10.12932/AP-200220-0773

63. Shi Y., Wang Y., Shao C., Huang J., Gan J., Huang X., Bucci E., Piacentini M., Ippolito G., Melino G. COVID-19 infection: the perspectives on immune responses. Cell Death Differ., 2020. doi: 10.1038/s41418-020-0530-3

64. Snijder E.J., Decroly E., Ziebuhr J. The nonstructural proteins directing coronavirus RNA synthesis and processing. Adv. Virus Res., 2016, vol. 96, pp. 59-126. doi: 10.1016/bs.aivir.2016.08.008

65. Song W., Gui M., Wang X., Xiang Y. Cryo-EM structure of the SARS coronavirus spike glycoprotein in complex with its host cell receptor ACE2. PLoS Pathog., 2018, vol. 14, no. 8: e1007236. doi: 10.1371/journal.ppat.1007236

66. Su S.,Wong G., Shi W., Liu J., Lai A.C.K., Zhou J., Liu W., Bi Y., Gao G.F. Epidemiology, genetic recombination, and pathogenesis of coronaviruses. Trends Microbiol., 2016, vol. 24, pp. 490-502.

67. Subissi L., Imbert I., Ferron F., Collet A., Coutard B., Decroly E., Canard B. SARS-CoV ORF1b-encoded nonstructural proteins 12-16: replicative enzymes as antiviral targets. Antiviral Res., 2014, vol. 101, pp. 122-130. doi: 10.1016/j.antiviral.2013.11.006

68. Tang X., Wu C., Li X., Song Y., Yao X., Wu X., Duan Y., Zhang H., Wang Y., Qian Z., Cui J., Lu J. On the origin and continuing evolution of SARS-CoV-2. Natl. Sci. Rev., 2020. doi: 10.1093/nsr/nwaa036

69. Tyrrell D.A., Bynoe M.L. Cultivation of viruses from a high proportion of patients with colds. Lancet, 1966, vol. 1, pp. 76-77.

70. Verschueren K.H., Pumpor K., Anemüller S., Chen S., Mesters J.R., Hilgenfeld R. a structural view of the inactivation of the SARS coronavirus main proteinase by benzotriazole esters. Chem. Biol., 2008, vol. 15, pp. 597-606.

71. Walls A.C., Tortorici M.A., Snijder J., Xiong X., Bosch B.J., Rey F.A., Veesler D. Tectonic conformational changes of a coronavirus spike glycoprotein promote membrane fusion. Proc. Natl. Acad. Sci., 2017, vol. 114, pp. 11157-11162. doi: 10.1073/ pnas. 1708727114 .

72. Wang L.F., Shi Z., Zhang S., Field H., Daszak P., Eaton B.T. Review of Bats and SARS. Emerg. Infect. Dis., 2006, vol. 12, pp. 12.

73. Wang W., Tang J., Wei F. Updated understanding of the outbreak of 2019 novel coronavirus (2019-nCoV) in Wuhan, China. $J$. Med. Virol., 2020, vol. 92, pp. 441-447. doi: 10.1002/jmv.25689.

74. Wilder-Smith A., Teleman M.D., Heng B.H., Earnest A., Ling A.E., Leo Y.S. Asymptomatic SARS coronavirus infection among healthcare workers, Singapore. Emerg. Infect. Dis., 2005, vol. 11, pp. 1142-1145. doi: 10.3201/eid1107.041165

75. Wilson M.E., Chen L.H. Travelers give wings to novel coronavirus (2019-nCoV). J. Travel Med., 2020, vol. 27 , iss. 2: taaa015. doi: 10.1093/jtm/taaa015

76. World Health Organization. Clinical management of severe acute respiratory infection when novel coronavirus (2019-nCoV) infection is suspected: Interim guidance. 28 January 2020. URL: https://apps.who.int/iris/handle/10665/330893

77. Wrapp D., Wang N., Corbett K.S., Goldsmith J.A., Hsieh C.L., Abiona O., Graham B.S., McLellan J.S. Cryo-EM structure of the 2019-nCoV spike in the prefusion conformation. Science, 2020, vol. 367, pp. 1260-1263. doi: 10.1126/science.abb2507.

78. Wu F., Zhao S., Yu B., Chen Y.M., Wang W., Song Z.G., Hu Y., Tao Z.W., Tian J.H., Pei Y.Y., Yuan M.L., Zhang Y.L., Dai F.H., Liu Y., Wang Q.M., Zheng J.J., Xu L., Holmes E.C., Zhang Y.Z. A new coronavirus associated with human respiratory disease in China. Nature, 2020, vol. 579, pp. 265-269. doi: 10.1038/s41586-020-2008-3

79. Yang Y., Du L., Liu C., Wang L., Ma C., Tang J., Baric R.S., Jiang S., Li F. Receptor usage and cell entry of bat coronavirus HKU4 provide insight into bat-to-human transmission of MERS coronavirus. PNAS, 2014, vol. 111, pp. 12516-12521. doi: 10.1073/ pnas. 1405889111

80. Yeh K.M., Chiueh T.S., Siu L.K., Lin J.C., Chan P.K., Peng M.Y., Wan H.L., Chen J.H., Hu B.S., Perng C.L., Lu J.J., Chang F.Y. Experience of using convalescent plasma for severe acute respiratory syndrome among healthcare workers in a Taiwan hospital. J. Antimicrob. Chemother., 2005, vol. 56, pp. 919-922.

81. Yount N.Y., Andrés M.T., Fierro J.F., Yeaman M.R. The gamma-core motif correlates with antimicrobial activity in cysteinecontaining kaliocin-1 originating from transferrins. Biochim. Biophys. Acta, 2007, vol. 1768, pp. 2862-2872.

82. Yuan L., Chen Z., Song S., Wang S., Tian C., Xing G., Chen X., Xiao Z.X., He F., Zhang L. p53 degradation by a coronavirus papain-like protease suppresses type I interferon signaling. J. Biol. Chem., 2015, vol. 290, pp. 3172-3182. doi: 10.1074/jbc. M114.619890

83. Zhang C., Wang X.M., Li S.R., Twelkmeyer T., Wang W.H., Zhang S.Y., Wang S.F., Chen J.Z., Jin X., Wu Y.Z., Chen X.W., Wang S.D., Niu J.Q., Chen H.R., Tang H. NKG2A is a NK cell exhaustion checkpoint for HCV persistence. Nat. Commun., 2019, vol. 10, no. 1: 1507. doi: 10.1038/s41467-019-09212-y 
84. Zheng M., Gao Y., Wang G., Song G., Liu S., Sun D., Xu Y., Tian Z. Functional exhaustion of antiviral lymphocytes in COVID-19 patients. Cell. Mol. Immunol., 2020. doi: 10.1038/s41423-020-0402-2

85. Zhou P., Yang X.L., Wang X.G., Hu B., Zhang L., Zhang W., Si H.R., Zhu Y., Li B., Huang C.L., Chen H.D., Chen J., Luo Y., Guo H., Jiang R.D., Liu M.Q., Chen Y., Shen X.R., Wang X., Zheng X.S., Zhao K., Chen Q.J., Deng F., Liu L.L., Yan B., Zhan F.X., Wang Y.Y., Xiao G.F., Shi Z.L. A pneumonia outbreak associated with a new coronavirus of probable bat origin. Nature, 2020, vol. 579, no. 7798, pp. 270-273. doi: 10.1038/s41586-020-2012-7

\section{Авторы:}

Исихак Ф.А., доцент кафедры микробиологии Колледжа ветеринарной медицины Мосульского университета, г. Мосул, Ирак;

Хамад М.А., доцент кафедры микробиологии Колледжа ветеринарной медицины Мосульского университета, г. Мосул, Ирак;

Мустафа Н.г., профессор, зав. кафедрой физиологии, биохимии и фармакологии Колледжа ветеринарной медицины Мосульского университета, г. Мосул, Ирак.

\section{Authors:}

Isihak F.A., Assistant Professor, Department of Microbiology, College of Veterinary Medicine, University of Mosul, Mosul, Iraq; Hamad M.A., Assistant Professor, Department of Microbiology, College of Veterinary Medicine, University of Mosul, Mosul, Iraq; Mustafa N.G., Professor, Head of Department of Physiology, Biochemistry, and Pharmacology, College of Veterinary Medicine, University of Mosul, Mosul, Iraq. 
Иллюстрации к статье "COVID-19: обновленный взгляд" (авторы: Ф.А. Исихак, М.A. Хамад, Н.Г. Мустафа) (с. 247-258)

Illustrations for the article "COVID-19: an updated review" (authors: Isihak F.A., Hamad M.A., Mustafa N.G.) (pp. 247-258)
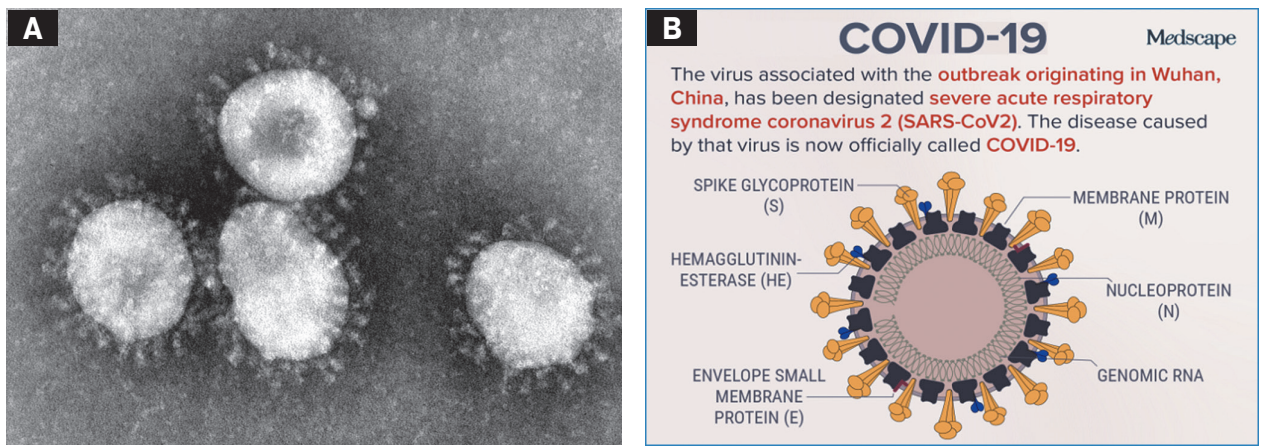

Figure 2. Human coronavirus. A) EM photo. B) Structure [13]

\section{SARS-CoV-2}

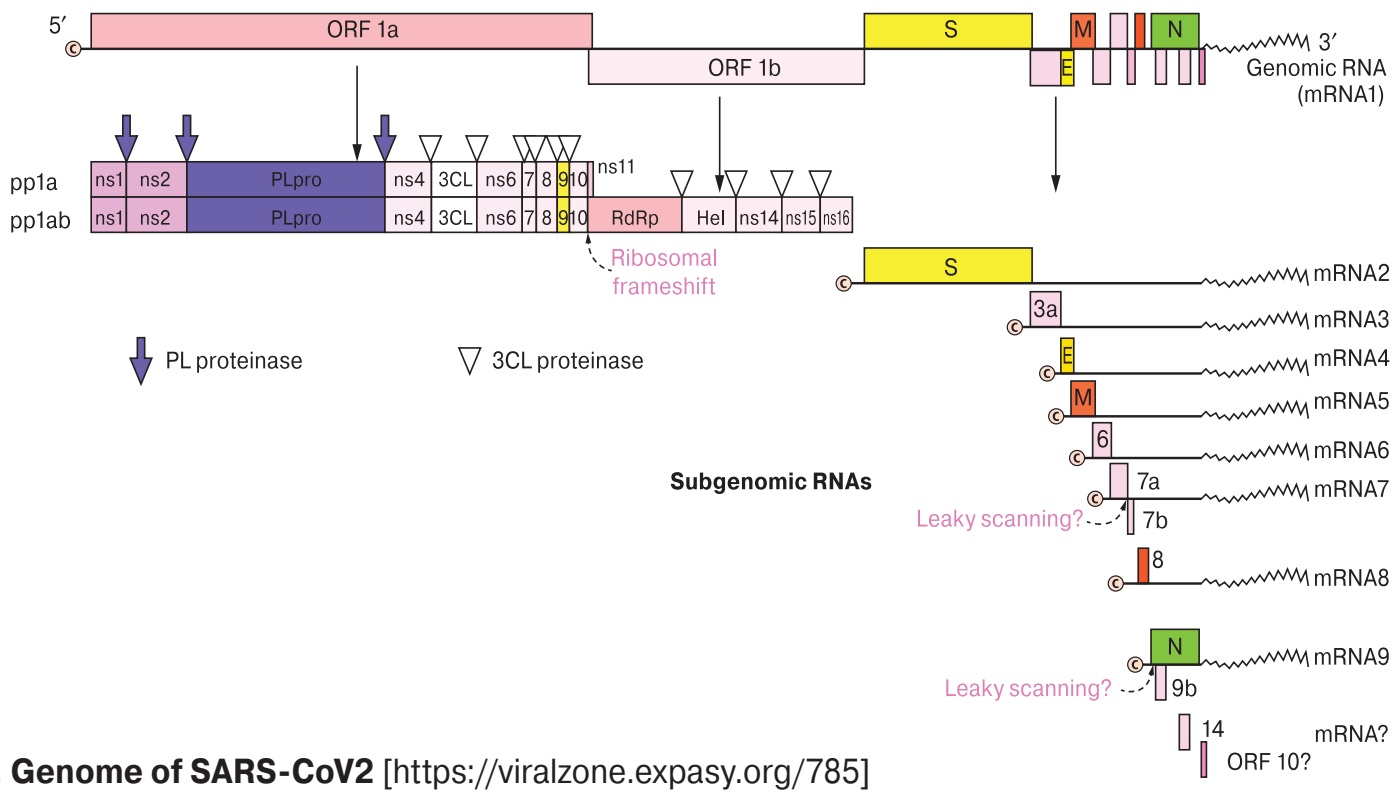

Figure 3. Genome of SARS-CoV2 [https://viralzone.expasy.org/785]

A

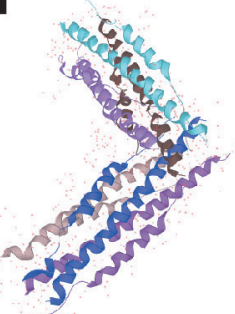

D

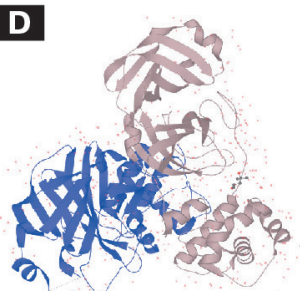

B

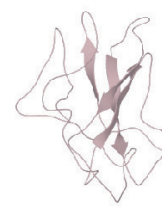

E

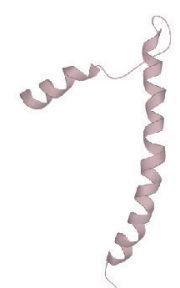

C

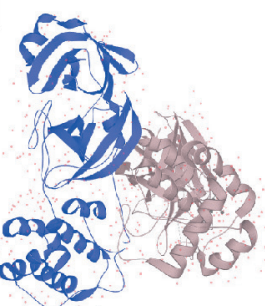

$\mathbf{F}$

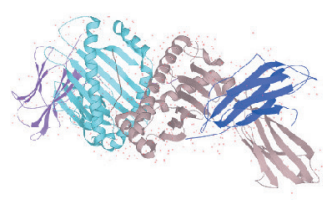

Figure 4. SARS-CoV proteins structure (A. Spike. B. Nucleoprotein.

C. Replicase polyprotein 1a. D. Replicase polyprotein 1ab.

E. Envelop small membrane protein. F. M protein)

[https://www.uniprot.org/uniprot/?query=human+sars+coronavirus]

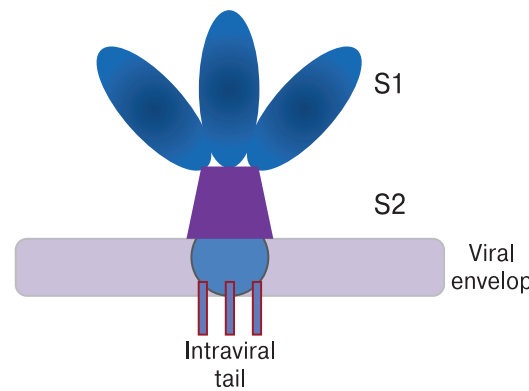

Figure 5. Suggested structure of spike 
Иллюстрации к статье "COVID-19: обновленный взгляд” (авторы: Ф.А. Исихак, М.A. Хамад, Н.Г. Мустафа) (с. 247-258)

Illustrations for the article "COVID-19: an updated review" (authors: Isihak F.A., Hamad M.A., Mustafa N.G.) (pp. 247-258)

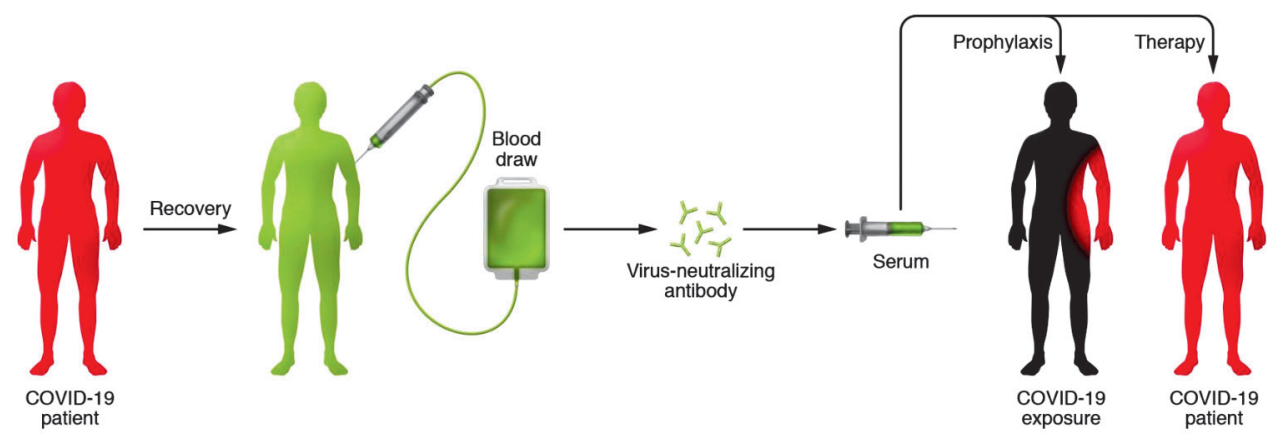

Figure 6. Graphic of convalescent sera used for containing COVID-19 [11]

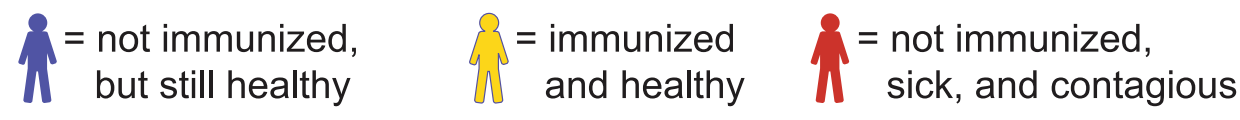


Some of the population gets immunized

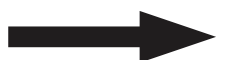

Contagious disease spreads through some of the population


Figure 7. Herd immunity [https://commons.wikimedia.org/wiki/File:Community_Immunity.jpg] 